\title{
DAMPAK LINGKUNGAN KERJA SOSIAL DAN INSENTIF PADA SEMANGAT KERJA KARYAWAN INDUSTRI PARIWISATA
}

\author{
Muhammad Rizal Nugroho \\ Universitas Pendidikan Indonesia \\ muhammad.rizal19@student.upi.edu \\ H. Syamsul Hadi Senen \\ Universitas Pendidikan Indonesia \\ syamsulhadisenen@upi.edu \\ H. Eded Tarmedi \\ Universitas Pendidikan Indonesia \\ ededtarmedi@upi.edu
}

\begin{abstract}
ABSTRAK
Tujuan penelitian - Tujuan dari makalah ini adalah untuk mengetahui dampak lingkungan kerja sosial dan insentif pada semangat kerja karyawan industri pariwisata.

Model/metode penelitian/pendekatan - Model penelitian ini memakai model cross- sectional. Penelitian ini menggunakan pendekatan deskriptif dan verifikatif dengan metode survei. Sebanyak 84 responden dipilih sebagai simple random sampling. Survei menggunakan instrumen penelitian berupa kuesioner untuk mengumpulkan data dari responden. Teknik analisis data yang digunakan dalam penelitian ini memakai regresi linier.

Temuan penelitian - Terdapat hasil positif mengenai dampak lingkungan kerja sosial dan insentif pada semangat kerja karyawan industri pariwisata.

Orisinalitas/Nilai - Penelitian ini mengangkat permasalahan bagaimana cara peningkatan semangat kerja karyawan melalui lingkungan kerja sosial dan insentif. Perbedaan penelitian ini dengan penelitian sebelumnya pada objek yang digunakan, variabel yang digunakan, mendukung teori serta referensi yang berbeda yang digunakan oleh peneliti sebelumnya.
\end{abstract}

Kata kunci: Dampak lingkungan kerja, lingkungan kerja sosial, insentif, semangat kerja, industri pariwisata.

Jenis Jurnal: Artikel Penelitian

\section{PENDAHULUAN}

Pada lingkungan usaha, Sumber Daya Manusia (SDM) telah menjadi salah satu faktor yang penting dalam pencapaian tujuan perusahaan, (Mulyadi, 2010) Sumber Daya Manusia (SDM) adalah faktor sentral dalam suatu organisasi. Apapun bentuk serta tujuannya, organisasi dibuat berdasarkan berbagai visi untuk kepentingan manusia dan dalam pelaksanaan misinya dikelola dan diatur oleh manusia sebagai sumber daya yang strategis dalam kegiatan institusi maupun organisasi. Tanpa adanya manusia dalam suatu perusahaan, tidak akan mungkin perusahaan tersebut dapat berkembang dan maju sesuai dengan yang diharapkan. Salah satu faktor yang mempengaruhi kinerja Sumber Daya Manusia (SDM) salah satunya yaitu semangat kerja karyawan itu sendiri. Semangat kerja karyawan tentu harus menjadi bahan pertimbangan oleh perusahaan, bahwa dengan adanya semangat kerja yang baik maka perusahaan pun dapat diuntungkan dengan adanya komunikasi yang baik antar Sumber Daya
Manusia (SDM), sehingga tujuan perusahaan pun akan lebih mudah untuk dicapai.

(Wibowo Adi, 2007) Pariwisata merupakan salah satu penggerak roda perekonomian dunia yang terbukti mampu memberikan kontribusi terhadap kemakmuran suatu negara. Dalam dunia pariwisata semangat kerja karyawan menjadi hal yang sangat penting, dengan semangat kerja yang tinggi tentu karyawan akan memberikan pelayanan yang baik terhadap tamunya. Hal ini senada dengan pendapat dari (Ann Lasala \& Bjarnason, 2010) menyebutkan bahwa karyawan yang memiliki semangat kerja yang tinggi akan memiliki tanggung jawab yang tinggi terhadap pekerjaannya.

Namun hal ini berbeda dengan keadaan di beberapa resort yang berada di sekitar Bandung khususnya di daerah Subang. Hal ini tidak diikuti dengan kinerja yang baik, ditunjukkan dengan menurunnya semangat kerja karyawan.

Fenomena ini menjelaskan bahwa tingkat semangat kerja karyawan sangatlah penting, sesuai dengan pendapat (Zendy, 2012) 
mengemukakan bahwa semangat kerja yang tinggi akan memberikan dampak positif bagi perusahaan, sebaliknya semangat kerja yang rendah akan merugikan perusahaan seperti tingkat absensi yang tinggi, perpindahan karyawan, dan produktifitas yang rendah.

Selain dengan menurunnya tingkat kehadiran, indikator lain yang menjadi pendukung menurunnya semangat kerja karyawan diperlihatkan dengan meningkatnya pelanggaran disiplin kerja yang dilakukan oleh karyawan.

Adapun dampak lain yang disebabkan turunnya semangat kerja karyawan yaitu dengan meningkatnya presentase turnover. Terdapat beberapa faktor yang mempengaruhi semangat kerja karyawan, yaitu lingkungan kerja sosial, hal ini sesuai dengan pendapat Nitisemito (2003:159) mengemukakan bahwa "Lingkungan kerja sosial yang dianggap kurang baik, artinya kurang terciptanya hubungan yang harmonis antara rekan dengan rekan, rekan dengan pimpinan bahkan pimpinan dengan pimpinan dapat menghambat semangat kerja karyawan, suasana kerja bahkan peralatan yang kurang mendukung."

Selain itu menurut (Sunyoto, 2012) dalam Lidya Agustina Siregar menyatakan bahwa, "Dengan memperhatikan lingkungan kerja sosial yang baik atau menciptakan kondisi kerja yang mampu memberikan motivasi untuk bekerja, maka akan membawa pengaruh terhadap kegairahan atau semangat kerja." (Sumber: http://repository.usu.ac.id). Hal ini diperkuat dengan pernyataan dari (Herzberg, 2003) dalam James Winkelhorst Saavedra "An employee's morale is closely correlated to his job and job environment and as the environment changes so does the morale."

Lingkungan kerja sosial karyawan merupakan hal yang sangat penting dalam sebuah perusahaan. Hal ini menunjukkan bahwa apa yang dilakukan perusahaan dalam membangun hubungan kerja yang baik memerlukan pengendalian emosional yang baik di lingkungan kerja. Namun dalam pelaksanaan programnya perusahaan masih mengalami kendala.

Adapun faktor lain yang mempengaruhi semangat kerja menurut (Mathis, 2010) yaitu gaji (kompensasi), pendidikan dan pelatihan, promosi, dan lingkungan kerja. Melihat kompensasi menjadi salah satu faktor yang mempengaruhi semangat kerja di suatu perusahaan, maka kompensasi mempunyai peran dalam meningkatkan semangat karyawan. Hal ini senada dengan (Danti, F. P., hakam, M. S., Mukzam, 2014) pemberian kompensasi yang baik kepada para karyawan yang berprestasi akan berdampak pada semangat kerja yang tinggi dari para karyawan itu sendiri sehingga karyawan akan lebih bersemangat dalam bekerja.
Mengingat pentingnya semangat kerja karyawan untuk keberlangsungan perusahaan, ditemukan pemecahan permasalahan semangat kerja yaitu dengan meningkatkan bentuk lingkungan kerja dan kompensasi pada perusahaan.

\section{KAJIAN PUSTAKA}

Schultz dalam (A.A Anwar Prabu Mangkunagara, 2010) Lingkungan kerja sosial adalah semua aspek non fisik kerja, psikologis kerja dan peraturan kerja yang dapat mempengaruhi semangat kerja dan produktivitas kerja. Menurut Sutermeister (1976:57) dalam (Hadi Senen \& Taufan H, 2009) mengemukakan "The major factors which establish the social condition in an organization are considered to be formal organization, informal organization or groups, leaders and supervisors and the union."

(Rivai \& Sagala, 2014) Bentuk pembayaran yang dikaitkan dengan kinerja dan gainsharing, sebagai pembagian keuntungan bagi karyawan akibat peningkatan produktivitas atau penghematan biaya. Dimana pengguna insentif yang dibayarkan pada karyawan atas dasar produksinya melebihi standar yang ditetapkan. Sesuai pendapat (Rivai \& Sagala, 2014) ada 8 dimensi dari insentif, yaitu: piecework, production bonus, commission, maturity curve, pay for knowledge/pay for skill compensation, nonmonetary incentive.

(Moekijat, 2010) Semangat kerja menggambarkan perasaan berhubungan dengan jiwa, semangat kelompok, kegembiraan dan kegiatan. Apabila karyawan nampak merasa senang, optimis mengenai kegiatan dan tugas serta ramah satu sama lain, maka karyawan itu dikatakan mempunyai semangat yang tinggi. Sebaliknya, apabila karyawan nampak tidak puas, lekas marah, sering sakit, suka membantah, gelisah, dan pesimis, maka reaksi ini dikatakan sebagai bukti semangat yang rendah. Indikatorindikator semangat kerja menurut (Moekijat, 2010) terdiri dari: Kegembiraan, kerjasama, kebanggaan dalam bekerja, tanggung jawab, kesetiaan

(Wursanto, 2009) mengemukakan bahwa lingkungan kerja sosial dapat memberikan dorongan dan semangat kerja yang tinggi. (Djoko $\mathrm{W}, 2013$ ) dalam jurnalnya lingkungan kerja sosial berpengaruh terhadap semangat kerja, semakin baik lingkungan kerja perusahaan artinya semakin baik semangat kerja karyawan yang pada akhirnya akan berdampak positif pada peningkatan kinerja karyawan. Selain itu menurut (Gorda, 2004) mengatakan bahwa yang mempengaruhi semangat kerja karyawan salah satunya adalah lingkungan kerja dan komunikasi. Adapun menurut Nitisemito (2008:85) 
lingkungan kerja dalam suatu organisasi mempunyai peranan penting terhadap kelancaran pelaksanaan pekerjaan, karena lingkungan kerja yang baik bukan saja dapat memuaskan karyawan dalam melaksanakan tugas, tetapi berpengaruh juga dalam meningkatkan semangat kerja dan produktivitas.

Selain lingkungan kerja yang dapat mempengaruhi semangat kerja yaitu kompensasi. (Mathis, 2001) yaitu gaji (kompensasi), pendidikan dan pelatihan, promosi, lingkungan kerja. Selain itu, menurut (P. Robbins, 2003) faktor-faktor yang dapat mempengaruhi semangat kerja karyawan adalah kerja yang secara mental menantang, ganjaran yang pantas, kondisi kerja yang mendukung, rekan kerja yang mendukung, dan kesesuaian kepribadian dengan pekerjaan. (Agus, Dharma, \& Putra, 2015) kompensasi memiliki pengaruh signifikan terhadap semangat kerja, hasil tersebut sesuai dengan hasil penelitian ini yang menemukan bahwa kompensasi secara langsung memiliki pengaruh signifikan terhadap semangat kerja. (Fitria, 2013) dalam jurnalnya menyatakan adanya pengaruh lingkungan kerja sosial dan insentif secara bersama-sama berpengaruh terhadap semangat kerja karyawan.

Gambar 1 Paradigma Penelitian

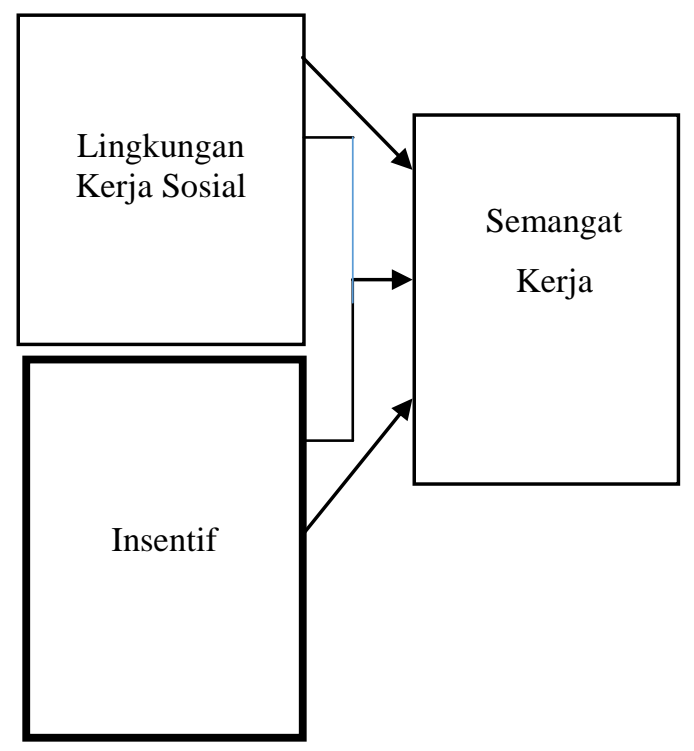

\section{METODE PENELITIAN}

Objek penelitian dalam penelitian ini adalah lingkungan kerja sosial, insentif dan semangat kerja. Adapun yang menjadi variabel bebas dalam penelitian ini adalah lingkungan kerja sosial, insentif dan variabel terikatnya adalah semangat kerja. Populasi dalam penelitian ini sebanyak 544 responden, karena populasi berjumlah lebih dari 100 maka digunakan teknik probability sampling, sehingga di ambil sampel sebanyak 84 responden.
Penelitian ini dilakukan pada kurung waktu kurang dari satu tahun, maka metode penelitian yang digunakan adalah explanantory survey. Jenis penelitan yang digunakan adalah penelitian deskriptif dan verifikatif. Suharsimi Arikunto (2004:7) dalam jurnal (Girang, 2008) penelitian verifikatif pada dasarnya ingin menguji kebenaran melalui pengumpulan data di lapangan. (Lisnawati, 2016) Penelitian deskriptif bertujuan untuk memperoleh gambaran, sesuai dengan rumusan masalah. Dengan demikian, maka dalam penelitian ini akan dilakukan pengujian mengenai seberapa besar pengaruh lingkungan kerja sosial dan insentif terhadap semangat kerja. Berdasarkan jenis penelitian tersebut, maka metode yang digunakan dalam penelitian ini adalah explanatory survey yang bertujuan untuk menguji hipotesis antara variabel yang satu dengan variabel yang lain.

\section{HASIL PENELITIAN \& PEMBAHASAN}

Untuk menguji signifikansi pengaruh lingkungan kerja sosial dan insentif terhadap semangat kerja karyawan diguakan uji F, yaitu membandingkan antara $\mathrm{F}_{\text {hitung }}$ dan $\mathrm{F}_{\text {tabel }}$. Rumus uji $\mathrm{F}$ atau uji ANOVA dijelaskan pengujian uji $\mathrm{F}$ yang dilihat dari Anova dengan tingkat probabilitas (Sig.) $=0,000$, dengan taraf signifikansi 0,05 yaitu $0,000 \leq 0,05$. Artinya terdapat pengaruh yang positif antara pengaruh lingkungan kerja sosial dan insentif terhadap semangat kerja karyawan.

Peneliti juga melakukan pengujian pengaruh variabel bebas secara bersama-sama terhadap variabel terikat dengan menggunakan uji $\mathrm{F}$ yaitu $F_{\text {hitung }}>F_{\text {tabel }}$. Maka $F_{\text {tabel }}$ dengan 84 responden yaitu pada $\mathrm{a}=0,05$ adalah 3,95 . Sehingga didapat 53.943>3,95, Dengan demikian dapat disimpulkan bahwa hipotesis dalam penelitian ini yaitu $\mathrm{H}_{\mathrm{o}}$ ditolak dan $\mathrm{H}_{1}$ diterima. Maka diperoleh persamaan regresi linear berganda antar komitmen organisasi dan motivasi kerja dengan kinerja karyawan.

Berdasarkan persamaan regresi linear diatas, konstanta sebesar 4.702, artinya jika tidak ada lingkungan kerja sosial dan insentif, maka besarnya kinerja karyawan sebesar 4.702. Koefisien regresi 0,340 satu satuan nilai artinya setiap terjadi peningkatan lingkungan kerja sosial akan meningkatkan semangat kerja karyawan sebesar 0,340 satu satuan nilai dan sebaliknya jika terjadi penurunan semangat kerja, lingkungan kerja sosial akan menurunkan semangat kerja karyawan sebesar 0,340 satu satuan nilai. Koefisien regresi 0,441 satu satuan nilai artinya setiap terjadi peningkatan insentif akan meningkatkan semangat kerja karyawan sebesar 0,441 satu satuan nilai dan sebaliknya jika terjadi 
penurunan, insentif akan menurunkan semangat kerja 0,441 satu satuan nilai.

Untuk mengetahui besarnya pengaruh variabel lingkungan kerja sosial terhadap semangat kerja, insentif terhadap semangat kerja dan pengaruh lingkungan kerja sosial dan insentif terhadap semangat kerja, maka digunakan rumus koefisien determinasi sebagai berikut:

$$
\mathrm{KD}=\mathbf{r}^{2} \times 100
$$

Hasil perhitungan koefisien determinasi untuk lingkungan kerja sosial terhadap semangat kerja adalah 47\%, artinya semangat kerja dipengaruhi oleh lingkungan kerja sosial sebesar $47 \%$, sedangkan $53 \%$ dipengaruhi oleh variabel selain lingkungan kerja sosial.

Koefisien determinasi untuk insentif terhadap semangat kerja adalah $48 \%$, artinya semangat kerja dipengaruhi oleh insentif sebesar $48 \%$, sedangkan $52 \%$ dipengaruhi oleh variabel selain insentif.

Koefisien determinasi untuk lingkungan kerja sosial dan insentif terhadap semangat kerja adalah $57 \%$, artinya semangat kerja dipengaruhi $57 \%$ oleh lingkungan kerja sosial dan insentif, sedangkan $43 \%$ dipengaruhi oleh variabel lain yang tidak diteliti dalam penelitian ini. Nilai tersebut dapat dilihat juga dalam output koefisien korelasi pada lambang $r$ square.

\section{KESIMPULAN}

Berdasarkan pembahasan teori, hasil penelitian, dan pengujian analisis regresi linear berganda yang dilakukan mengenai pengaruh lingkungan kerja sosial dan insentif terhadap semangat kerja dapat disimpulkan lingkungan kerja sosial dan insentif mempunyai pengaruh positif terhadap semangat kerja dengan tingkat korelasi 57\%, hal ini menunjukkan bahwa semakin tinggi lingkungan kerja sosial dan insentif maka akan semakin tinggi juga semangat kerja karyawan, begitu pula sebaliknya semakin rendah lingkungan kerja sosial dan insentif maka semakin rendah pula semangat kerja karyawan tersebut.

\section{REKOMENDASI}

Berdasarkan hasil penelitian, maka peneliti merekomendasikan beberapa hal mengenai pelaksanaan program lingkungan kerja sosial dan insentif yang dapat meningkatkan semangat kerja karyawan.

Hasil penelitian menyatakan bahwa lingkungan kerja sosial dan insentif berpengaruh positif terhadap semangat kerja karyawan, maka dengan demikian penulis merekomendasikan agar perusahaan tetap menjaga, mempertahankan, mengawasi dan meningkatkan semangat kerja karyawan melalui lingkungan kerja sosial dan insentif untuk mewujudkan tujuan perusahaan.

\section{DAFTAR PUSTAKA}

A.A Anwar Prabu Mangkunagara. (2010). Prilaku dan Budaya Organisasi. Bandung: Repika Aditama.

Agus, I. G. D., Dharma, A., \& Putra, M. S. (2015). Semangat Kerja Karyawan Dan Kinerja Karyawan Pada PT United Indobali Denpasar, 1-16.

Ann Lasala, C., \& Bjarnason, D. (2010). Creating Workplace Environments that Support Moral Courage. Moral Courge, Vol. 15(In nursing), 2010.

Danti, F. P., hakam, M. S., Mukzam, M. D. (2014). Pengaruh kompensasi terhadap semangat kerja karyawan (studi kasus pada karyawan CV. Sejahtera, Pakisaji, Malang). Jurnal Administrasi Bisnis, 9(2), 1-9.

Djoko W, H. (2013). Pengaruh Motivasi, Lingkungan Kerja, Dan Kompensasi Terhadap Kinerja Karyawan Melalui Semangat Kerja Karyawan (Studi Kasus Pada Karyawan Bagian Produksi CV. Putra Jaya Sahitaguna, Semarang). Jurnal Sosial Dan Pilitik, 5.

Fitria, R. (2013). Pengaruh Lingkungan Kerja dan Insentif Terhadap Semangat Kerja Pegawai Pada Dana Pensiun PT. BPD Sumatera Barat. Journal Semangat Kerja, 53(9), 116.

Girang, R. (2008). Sales Promotion Berpengaruh Pada Keptusan Pengguna Kartu Kredit BNI. Jurnal Strategic, 7(14), 16-82.

Gorda. (2004). Manajemen Sumber Daya Manusia. (W. K. Gematama, Ed.). Denpasar.

Hadi Senen, S., \& Taufan H, G. (2009). Pengaruh Lingkungan Kerja, Karakteristik Individu Dan Motivasi Terhadap Kepuasan Kerja Karyawan Pada PT. Nyonya Meneer Di Semarang, 2.

Herzberg, F. (2003). Dasar-Dasar Manajemen . (Edisi Ke 2). Jakarta: Bumi Aksara.

Lisnawati. (2016). Analisis Persepsi Virtual Brand Terhadap Kinerja Ekuitas Merek. Business Management and Enterpreneurship Education, 1(1), 158173.

Mathis, R. (2001). Manajemen Sumber Daya Manusia (Buku kedua). Jakarta.

Mathis, R. (2010). Manajemen Sumber Daya Manusia. Jakarta: Salemba Empat.

Moekijat. (2010). Manajemen Sumber Daya Manusia. Bandung: Mandar Maju.

Mulyadi, H. (2010). Kondisi Motivasi dan Produktivitas Kerja Karyawan Pada PT . Galamedia Bandung Perkasa. Manajerial, 9, 97-111.

P. Robbins, S. (2003). Organizational Behavior (Edisi 10). Jakarta: PT Macanan Jaya 
Journal of Business Management Education | Volume 1, Number 3, December 2016, page. 1-5

Cemerlang.

Rivai, V., \& Sagala, E. J. (2014). Manajemen Sumber Daya Manusia untuk Perusahaan (III). Jakarta: Raja Grafindo.

Sunyoto, D. (2012). Manajemen Sumber Daya Manusia. Yogyakarta: CAPS.

Wibowo Adi, L. (2007). Tourist Product Attribute and Trust to Tourist Satisfaction and Loyalty A Study of Mini Vacation in
Bandung. Manajemen Pemasaran

Pariwisata, 1-41.

Wursanto. (2009). Dasar-dasar Ilmu Organisasi. Yogyakarta: Andi.

Zendy, P. (2012). Pengaruh Kompensasi, Kepemimpinan dan Motivasi Terhadap Semangat Kerja Karyawan LPD Desa Adat Kuta, 1,9 . 